\title{
Determinants Factors of Crafters Performance of SME's at Tapis, Province of Lampung
}

\author{
${\text { Mieke Rahayu }{ }^{1, *} \text {, Betty Magdalena }}^{2}$ \\ ${ }^{1}$ Department of Management, Institute of Informatics and Business Darmajaya, Lampung 34152, Indonesia \\ *miekerahayu@gmail.com \\ ${ }^{2}$ Department of Management, Institute of Informatics and Business Darmajaya, Lampung 34152, Indonesia \\ bettymagdalena1969@gmail.com \\ *Email corresponding author
}

Received 27 January 2021, Revised 15 February 2021, Accepted 15 March 2021

\begin{abstract}
This study aims to analyze and prove empirically the influence of managerial ability, work culture, organizational characteristics both partially and simultaneously on the innovation capability and performance of crafters at Tapis SMEs in Lampung Province. The research methods in this research are descriptive and verification methods. The population was 1,302 Tapis crafter in Lampung Province and a sample of 305 and as owner crafters as respondents, with questionnaires as data collection techniques, and data analysis technique was Structural Equation Modeling (SEM), using Lisrel 8.70. The results showed that partially or simultaneously, managerial ability, work culture, and organizational characteristics had a positive and significant influence on the capability of innovation. The results of this study also showed a positive effect of managerial ability, work culture, and innovation capabilities on the performance of crafters at Tapis SMEs in Lampung Province. Innovation capability can act as an intervening variable that strengthens the influence of managerial ability, organizational culture, and organizational characteristics on the performance of crafters the most dominant work culture influences the performance of craftsmen is 0.356 .

Keywords: managerial ability, work culture, organizational characteristics, innovation capability, performance, crafters, SMEs
\end{abstract}

\begin{abstract}
Abstrak - Penelitian ini bertujuan untuk menganalisis dan membuktikan secara empiris pengaruh kemampuan manajerial, budaya kerja, karakteristik organisasi baik secara parsial maupun simultan terhadap kapabilitas inovasi dan kinerja pengrajin pada UKM Tapis di Provinsi Lampung. Metode penelitian dalam penelitian ini adalah deskriptif dan verifikatif. Populasi dalam penelitian ini adalah 1.302 perajin Tapis di Provinsi Lampung dan sampel sebanyak 305 perajin pemilik sebagai responden, teknik pengumpulan data dengan kuesioner dan teknik analisis adalah Structural Equation Modeling (SEM), menggunakan Lisrel 8.70. Hasil penelitian menunjukkan bahwa secara parsial maupun simultan kemampuan manajerial, budaya kerja, dan karakteristik organisasi berpengaruh positif dan signifikan terhadap kapabilitas inovasi. Hasil penelitian ini juga menunjukkan adanya pengaruh positif antara kecakapan manajerial, budaya kerja, dan kapabilitas inovasi terhadap kinerja perajin pada UKM Tapis di Provinsi Lampung. Kapabilitas inovasi dapat berperan sebagai variabel intervening yang memperkuat pengaruh kemampuan manajerial, budaya organisasi, dan karakteristik organisasi terhadap kinerja perajin dengan pengaruh budaya kerja yang paling dominan terhadap kinerja pengrajin adalah 0,356 .
\end{abstract}

Kata Kunci: kemampuan manajerial, budaya kerja, karakteristik organisasi, kapabilitas inovasi, kinerja, pengrajin, UKM

\section{INTRODUCTION}

Micro, Small and Medium Enterprises (MSMEs) contribute greatly to the economy of Indonesia and ASEAN. To date, 96 percent of businesses in ASEAN are MSMEs, with a contribution to gross domestic product (GDP) of 30 percent to 57 percent and employing 50 percent to 95 percent of the workforce. Meanwhile, in Indonesia, MSMEs contribute a number of business units with a contribution to the national GDP of 57 percent, and employ more than 97 percent of the domestic workforce. Within this framework, the role of MSMEs becomes very important as the main driver of job creation and economic growth, both at the national and regional levels.

In 2017 , there was a significant absorption of labor in the industrial sector, reaching 33\%. This shows the occurrence of growth in the industrial sector which will have implications for national 
income. The contribution of employment to Micro Enterprises is 87.00 percent, while Large Enterprises (LE) is 3.30 percent; Small Business (SB) by 5.70 percent, and Medium Enterprises (ME) by 4.00 percent. This means that increasing the industrial sector provides opportunities and creates employment for the wider community. One of the advantages of MSME is its durability in dealing with crises. In Indonesia, MSMEs have been proven to be able to withstand economic shocks and become a savior for the economy in the 1997 financial crisis and the 2008 global crisis. This was partly due to the flexibility of MSMEs in adjusting their production processes, being able to develop with their own capital, and not depend on foreign debt.

Hajar (2015) states that the programs and activities carried out by the government to develop the MSME sector so far have been very satisfying. This fact is in line with the results of a study by Mochklas (2016), which concluded that the success of small and medium enterprises has a direct impact on economic development, both in developed and developing countries. In addition, SMEs are currently recognized as the main economic drivers in both developing and developed countries (Fatoki, 2011). One factor that contributes to the sustainability of SMEs is human resources. Chen (2011) asserts that human resources are the most important resources and the most active factors in economic activity. The success of small and medium-sized businesses also cannot be separated from the performance of individual human resources in managing the activities of SMEs. This initial study focuses on SMEs and illustrates that the quality of human resources in SMEs in improving individual performance is generally still low. This is due to limited educational qualifications, namely elementary school education and the highest is junior high school, while high school qualifications and even undergraduate education is still small.

Sulistiyani (2010) explained that SMEs need to manage activities, so research needs to be done relating to various variables that have contributed to the success of small and medium-sized businesses so as to form the results of performance of crafters and one of them is managerial ability. Management ability is a reflection of professional attitude, so that it will increase the degree of motivation, with managerial ability as a determinant of success, by creating work performance and efforts to achieve performance through the ability to plan and implement and the ability to make effective activities. In addition, work culture also has an impact on performance of crafters. Work culture is a person's perspective in giving meaning to work. Work culture according to Kurniawan et al. (2012) is a set of patterns of behavior that are inherent as a whole for each individual in an organization. Furthermore, organizational characteristics in small and medium enterprises including business scale and age criteria can determine the success of performance of crafters, such as limiting the number of workers and the length of business operations. This limitation distinguishes small and medium-sized companies from large companies.

Yanuarto \& Kumorohadi (2013) suggested that innovation is an action that gives resources and new abilities to create prosperity. In general, a strong relationship is found between innovation and company performance and has a positive and direct relationship. Rahab et al. (2011) states that innovation capability is the ability of an organization to develop and modify its products and technologies or to create new products and technologies. Innovation capability has an important influence on the company in making new breakthroughs to improve the performance of the company. One of the traditional products in small and medium businesses, which is currently still in great demand and is a concern and is well known by the people of Indonesia and even foreign countries, is woven fabric products. Indonesia is a country that has a lot of culture and one of the results of this weaving work can make business opportunities or business opportunities both locally, nationally and internationally. Woven fabric is the handmade product, directly by hand by the crafters, whose products seem unique and rare, so the process of making woven fabric requires quite a long time.

Tapis is a woven fabric originating from Lampung Province. Tapis woven cloth is a woman's clothing in the form of a sarong, made of woven cotton yarn and ornamental variety embroidered with gold or silver thread (nyucuk), a cloth woven with a hook and lock system. Ornamental motifs in the form of living trees and buildings that contain human motifs as a symbol of ancestral spirits. The filter craft was originally produced only for personal and family balancing needs as special women's clothing for attending traditional ceremonies. The type of filter cloth used is adjusted to the level / social status. As a traditional cloth and a characteristic of the people of Lampung, basically Tapis fabric is a type of traditional craft in an effort to harmonize life, both to the environment and the creator of the universe. According to data from the Office of Cooperatives and SMEs, Lampung Province, in 2017, there were 1,319 Tapis crafters (279 males and 1,040 females). Performance of Tapis weaving crafters in Lampung Province in 2015-2017 based on sales volume, sales turnover and sales profit has decreased.

Based on the background, problem identification, and problem limitation above, the research problem can be stated as find the influence of the managerial ability of the owner or the craftsman, work culture and organizational characteristic toward innovation capability of Tapis Weaving SMEs partially and simultaneously and the second problem is analyse the influence of managerial ability of the owner or the craftsman, work culture, organizational characteristic and innovation capability on the 
performance of crafters of Tapis Weaving SMEs in Lampung Province partially and simultaneously.

\section{METHODS}

The objectives of this study are descriptive and verification. The unit of analysis in this study is the crafters who are also the owner of Tapis Weaving SMEs in Lampung Province, and the target areas are Bandar Lampung, South Lampung (Natar), Pesawaran and Pringsewu. This research is an explanatory survey that will prove the causal relationship between independent variables, namely managerial ability, work culture and organizational characteristics; intervening variable, namely the innovation capability variable; and the dependent variable, namely performance of crafters. This study is also a correlational study, which is a study that seeks to see whether or not two or more variables have a relationship.

To measure managerial abilities in this study the following dimensions and indicators are used. Dimensions of Conceptual skills, with the indicators of The ability to think rationally in any situation, The ability to think creatively and innovatively, The ability to analyze undesirable conditions, The ability to increase knowledge and ideas, The ability to unite Vision and work Team, The ability to make a standard time to complete work, The ability to create work methods to facilitate the completion of work. Dimensions of Technical skills, with the indicators of The ability to solve problems properly and there are solutions and cooperation, The ability to make and design products, The ability to create product concepts that are of interest to consumers, The ability to be responsible for manufacturing products, The ability to solve problems and find solutions if the product is damaged, The ability to compete with the same product on the market. Dimensions of Human relation skills, with the indicators of The ability to communicate well with coworkers, The ability to be active participation in training, seminars related to work responsibilities, The ability to understand the reasons given for completing work, The ability to understand attitudes and behaviors between coworkers, The ability to create cooperative, effective, practical and diplomatic cooperation, The ability to accept attitudes, behavior in a situation.

To measure the variable of work culture in this study the following dimensions and indicators are used. Dimension of Attitudes towards Work, with the indicators of Prefer to work than other activities, Working attitude is not compulsion to maintain survival, Work hard, Exercise caution when working, Work carefully, Always enthusiastic and initiative in working. Dimension of Behaviors towards Work, with the indicators of Satisfaction at work, exceeding other activities, Creative and innovative, The ability to innovate towards the present, Responsible for the concept of new products, Helping fellow colleagues when they need help, Willingness to learn related to duties and obligations, Working together in completing the jobs.

To measure the variable of organizational characteristics in this study the following dimensions and indicators are used. Dimension of Business Age, with the indicators of Has produced products for 5 to 10 years, Has the ability to produce the products and increase demand, Has produced the quality and competitive products. Dimension of Business Scale, with the indicators of The number of workers is between 5 and 10 individuals, The level of education of the crafters. Dimension of Resources, with the indicators of Has created a current and sustainable product, Most of the crafters already have certain expertise, The availability of insightful and technological human resources, Availability of skilled and creative human resources.

To measure the variable of innovation capability in this study, the following dimensions and indicators are used Human Resources Capability, with the indicators of Existing human resources have innovation skills, Existing human resources actively participate in training, seminars, exhibitions and bazaars, Existing human resources who are creative in product development. Use of Technology, with the indicators of Existing human resources are able to use the internet in product promotion, Existing human resources are able to build networks, Existing human resources are able to market their products online. Interaction and Communication with Outsiders, with the indicators of Cooperating with third parties, Conducting exhibitions and bazaars, Doing partnerships with customers and consumers, Marketing Capability, with the indicators of Conducting product evaluation and identification, Introducing the latest products and designs, Determining product prices, Promoting products through exhibitions and bazaars, Selling offline and online. New Product Development, with the indicators of Always make product development plans and ideas, Always make competitive superior product plans, Always follow the latest designs and products. Operational and Production Capabilities, with the indicators of Ability to make product designs and innovations in accordance with consumer demand, Ability to modify products according to current trends, Ability to use effective and efficient raw materials, Ability to supervise and identify the quality of raw materials, Ability to plan and schedule production processes. Research and Development, with the indicators of Identifying market segments, Expanding market networks, Improving the product, Expanding product distribution.

To measure the variable of performance of crafters in this study the following dimensions and indicators are used. Target, with the indicators of Making a product plan of interest, Generating expected benefits. Quality, with the indicators of Producing quality products according to standards, Producing products according to internal and external 
orders, All crafters are committed to product quality. Time, with the indicators of Producing products on time, Producing products according to the time of completion and satisfied customers, All crafters are committed to the timeliness of work completion.

Primary data in this study refer to data of all research variables collected directly from research subjects, namely crafters, who are both owners or managers in Tapis Weaving SMEs in Lampung Province, with the target areas of Bandar Lampung, South Lampung, North Lampung, Central Lampung, Pringsewu, Pesawaran and Tanggamus. While secondary data is data or information needed in this study obtained through official or published sources. The study period is 12 months from June 2017 to August 2018. The population in this study were the crafters of Tapis weaving in Lampung Province with the target areas: Bandar Lampung, South Lampung (Natar), North Lampung, Central Lampung, Pringsewu, Pesawaran and Tanggamus. The population in this study were the number of crafters in Tapis weaving SMEs who are still active in cities/districts in Lampung Province, namely 1,302 crafters. The Slovin formula was used to determine samples. Based on this formula, by proportional random sampling, a sample of 305 respondents was obtained.

To analyze the effect of managerial ability, work culture and organizational characteristics on innovation capability, and the implications for the performance of crafters of Weaving SMEs in Lampung Province, first the data processing test was collected from the results of the questionnaire. Data collection instruments using a questionnaire must be valid and reliable. Therefore, before being used to collect data an instrument was tested using the validity and reliability of the research instrument. The results of testing the validity and reliability of 50 people showed that the instrument was valid and reliable, so it could be used to be distributed to all locations. Data were processed and analyzed using several analytical techniques, namely descriptive analysis, classic assumption test, and structural model analysis. The data processing and analysis has been processed by Microsoft Excel, SPSS, and LISREL application programs.

Referring to structural equation, the structural equation consists of two sub-structures as follows:

Sub-structure $\mathrm{I}: \mathrm{h}_{1}=\mathrm{g}_{1.1} \mathrm{X}_{1}+\mathrm{g}_{1.2} \mathrm{X}_{2}+\mathrm{g}_{1.3} \mathrm{X}_{3}+\mathrm{z}_{1}$

Sub-Structure II: $h_{2}=g_{2.1} X_{1}+g_{2.2} X_{2}+g_{2.3} X_{3}+b_{2.1} h_{1}+$ $\mathrm{Z}_{2}$

\section{Notes:}

$\mathrm{h}_{1}=$ Innovation capability (IC)

$\eta_{2}=$ Performance of crafters (PC)

$\xi_{1}=$ Managerial ability (MA)

$\xi_{2}=$ Work culture (WC)

$\xi_{3}=$ Organizational characteristics (OC)

$\mathrm{f}=$ correlation between exogenous path coefficients $\gamma=$ path coefficient of the exogenous to endogenous variable

$\beta=$ path coefficient of the endogenous to endogenous variable

$\varsigma=$ error term

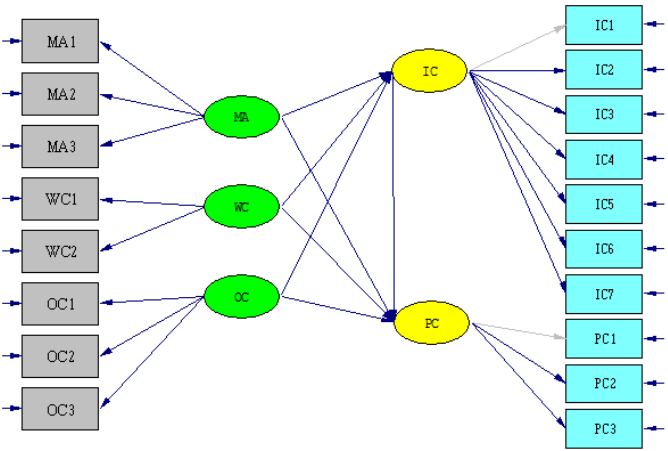

Figure 1. Path Diagram of Basic (Hybrid) Model

The hypotheses test of H1,H2, H3, H4, H5, H6, $\mathrm{H} 7, \mathrm{H} 8$, and $\mathrm{H} 9$ proposed in this study were analyzed by the critical values (CR) and p-values, to then be compared with the statistical limits required, i.e. above 1.96 for $\mathrm{CR}$ values and below 0.05 for $\mathrm{p}$-values, whereas for testing hypotheses $\mathrm{H} 4$ and $\mathrm{H} 9$ are performed by analyzing the calculated F-statistical values and $p$-values, from processing the data obtained, the F-statistic must be above the F-table and the p-value must be below 0.05 . If the results of data processing indicate the values that meet these requirements, then the proposed research hypotheses can be accepted.

\section{RESULTS AND DISCUSSION}

\section{Characteristics of the Respondents}

Based on gender, the majority of respondents were female $(79 \%)$ and male respondents were only $21 \%$. This condition shows that there are many female crafters because most mothers have part-time work in making Tapis weaving and as additional income for the family itself. In addition, the figure of women is more patient, painstaking and resilient in doing this work, and this can be seen from the number of female crafters who are more than the male. Based on the latest level of education it can be seen that the majority of crafters' educational levels are elementary school graduates, most of whom are also women or housewives, who do not work outside the home, who have part time jobs and are looking for additional household or family income. 


\section{Descriptive Analysis of The Variables}

The descriptive analysis of managerial ability of the crafter at Tapis Weaving SMEs in Lampung Province can be seen from the mean for each dimension in this variables, as follow.

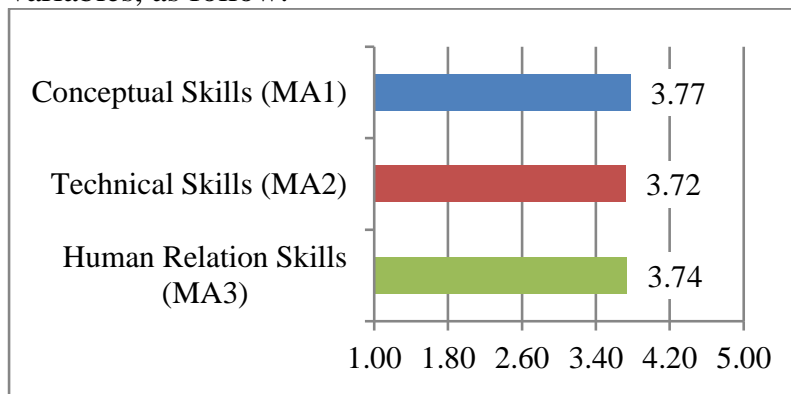

Figure 2. Average Score of Managerial Ability

The crafters, as well as the owner or manager, have and carry out three basic managerial abilities consisting of conceptual skills, technical skills, human relations skills in managing resources to achieve their goals appropriately. Managerial ability in Tapis weaving craftsmen in Lampung Province which has the highest average score is conceptual skills, with an average score of 3.77, while the Managerial ability in the Tapis weaving SMEs crafters in Lampung Province is the lowest with an average score achievement an average of 3.72 is technical skills. Technical skills are related to the ability to solve problems properly and there are solutions and cooperation; able to make and design products; able to create a product concept that interests consumers; responsible for manufacturing the product; able to solve problems and find solutions if the product is damaged, able to compete with the same product in the market.

Basically, conceptual skills, technical skills, and human relations skills are included in the high category so that their contribution to managerial ability is also high. This finding is in line with the opinion of Seen et al. (2012) which states that if a manager wants to succeed in his business as seen from performance, then a manager must have and carry out (1) Management Functions (2) Management Roles and (3) Management Skills. The three basic management skills referred to are conceptual skills, human relations skills and technical expertise. Likewise, in line with the opinion of McPherson (2007) which states that managerial ability is the ability to move resources to achieve their goals appropriately and consists of technical expertise, human relations skills and conceptual skill. While Sitohang's research proves that technical ability is a dominant factor influencing the performance of crafters of small weaving centers in Lamongan (Sitohang, 2010). The descriptive analysis of work culture of the crafter at Tapis Weaving SMEs in Lampung Province can be seen from the mean for each dimension in this variables, as follow.

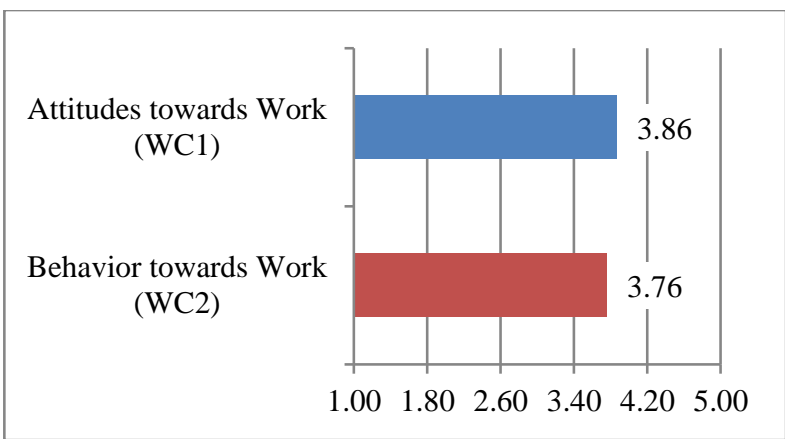

Figure 3. Average Score of Work Culture

Based on the figure above, the dimension of work culture of the crafter at Tapis Weaving SMEs in Lampung Province that has the highest average score is the Attitude towards Work (3.86), and the average score of Behavior towards Work is 3.76. In this sense, the Behavior towards Work is hardly to reflect the theory of work culture, that is, feel the satisfaction at work more than any other activity; always creative and innovative; able to innovate now; responsible for the product concept; likes to help fellow colleagues when they need help; have a willingness to learn related to my duties and obligations; cooperate with the Team in completing work.

The results of the analysis of the description above are in line with Ikupolati et al. (2017) that work culture is a philosophy that is based on a view of life as values that become the nature, habits, and driving forces, which then entrenched in the life of a community group or organization that is reflected in attitudes into behavior, beliefs, ideals, opinions and actions that manifest as work or work. Moreover, the results of research conducted by Rismawati (2017) states that work culture has a negative and not significant effect on performance of crafters. The descriptive analysis of organizational characteristics of the crafter at Tapis Weaving SMEs in Lampung Province can be seen from the mean for each dimension in this variables. Organizational characteristics of the crafter at Tapis Weaving SMEs in Lampung Province, that has the highest average score is business scale (3.87) and the dimension that has lower average score is resources (3.62). This shows that the business scale is more dominant in forming organizational characteristics variables than the dimension of resources.

Whereas Meliza (2013) found that company size had a significant relationship to performance. The descriptive analysis of innovation capability of the crafter at Tapis Weaving SMEs in Lampung Province can be seen from the mean for each dimension in this variables, as follow. 


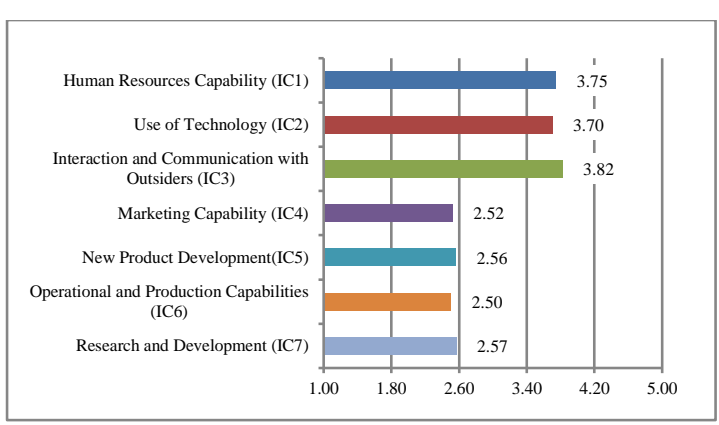

Figure 4. Average Score of Innovation Capability

The dimensions of innovation capability of the crafter at Tapis Weaving SMEs in Lampung Province that have higher average score are human resource capability (IC1), use of technology (IC2), and interaction and communication with outsiders (IC3). The dimensions that have low average scores are marketing capability (IC4), new product development (IC5), operational and production capabilities (IC6), and research and development (IC7).

This finding is in line with the opinion of Siyamtinah et al. (2011) that efforts to develop SMEs are constrained by traditional management, inadequate quality of human resources, scale and production techniques, innovation capability that is still low. The descriptive analysis of performance of the crafter at Tapis Weaving SMEs in Lampung Province can be seen from the mean for each dimension in this variables, as follow.

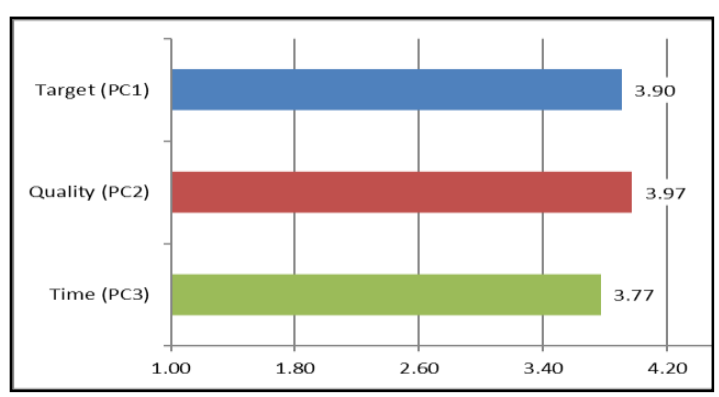

Figure 5. Average Score of Performance of Crafters

The dimension of performance of crafters at Tapis Weaving SMEs in Lampung Province that has highest average score is Quality (3.97), while the lowest is Time (3.77). This shows that the Performance of Crafters of Small and Medium Enterprises in Tapis Weaving in Lampung Province has a perception that quality is more dominant in shaping performance of crafters and in the time dimension of completing work is less dominant in forming performance of crafters variables.

\section{A. Verification Analysis}

Verification analysis is testing the hypothesis using SEM analysis, which consists of two stages. The measurement model explains the proportion of variance of each manifest variable that can be reflected in latent variables. Through the measurement model, it can be seen which manifest variable is more dominant in reflecting latent variables. This test is basically a test of data quality test (validity and reliability) of each latent variable using Confirmatory Factor Analysis (CFA). To get a more comprehensive picture, a second order test is done based on the achievements of each indicator for each manifest variable (dimension). After that, the first order test is done based on the achievement of each dimension for each latent variable.

The second stage is the evaluation of the inner model (structural model), which includes latent variable correlations, path coefficients, t-tests and $\mathrm{R}$ square $\left(\mathrm{R}^{2}\right)$, based on the normality test, linearity test, and homogeneity test, it was found that the data were normally distributed, had no problems with multicollinearity (linear), and did not have heteroscedasticity (homogeneous) problems. Thus, all statistical assumption requirements are met and can be continued with hypothesis testing using SEM analysis.

\section{Measurement model}

Measurement model is calculate using the LISREL program. The first order measurement model for all variables (MA, WC, OC, IC, and PC) in this study can be described as follows.

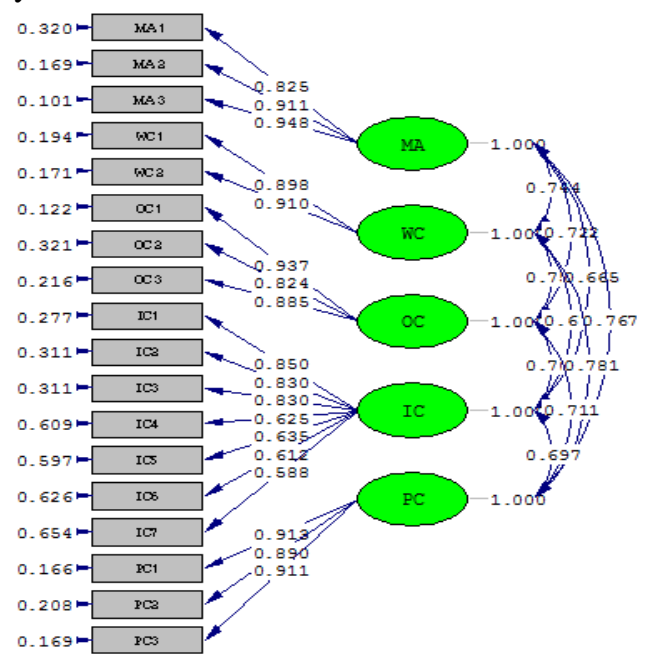

Figure 6. First Order Measurement Model

Referring to the measurement model, it can be stated that:

1. Managerial abilities (MA) can be formed by Conceptual skills, Technical skills, and Human relations skills, with the value of standardized loading factor (SLF) respectively 0.825, 0.911, and 0.948 . This shows that this managerial ability can best be reflected in human relations skills, followed by technical skills, and finally by conceptual skills.

2. Work culture (WC) can be formed by attitudes towards work and behavior towards work, with a standardized loading factor (SLF) value of 0.898 and 0.910 , respectively. This condition shows that work culture will be better if crafters can highlight more positive behavior towards work. 
3. Organizational characteristics (OC) can be formed by Company Age, Business Scale, and Resources, standardized loading factor (SLF) of $0.937,0.824$ and 0.885 , respectively. This shows that organizational characteristics in Tapis Weaving SMEs in Lampung Province can most be reflected in the business age, followed by resources, and finally business scale.

4. Innovation capability (IC) can be formed by HR Capabilities, Use of Technology, Interaction and Communication from Outside Parties, Marketing Capabilities, New Product Development, Operations and Production Capabilities, and Research and Development. The standardized loading factor (SLF) values respectively are $0.850,0.830,0.830,0.625,0.635,0.612$, and 0.588 . Referring to this value, crafters need to increase marketing capabilities, new product development, operational and production capabilities, and research and development so that innovation capability can be better.

5. Performance of crafters (PC) can be formed by Target, Quality, and Time, with the value of standardized loading factor (SLF) respectively $0.913,0.890$, and 0.911 . This condition shows that the performance of crafters is most reflected in the target, followed by time, and finally quality.

The calculation results show that all dimensions have a path loading / coefficient > 0.50 which indicates that each of these dimensions can significantly reflect each latent variable. Through the measurement model test results can be seen the path coefficient of each manifest variable. Overall, the basic model diagram for this model can be described as follows.

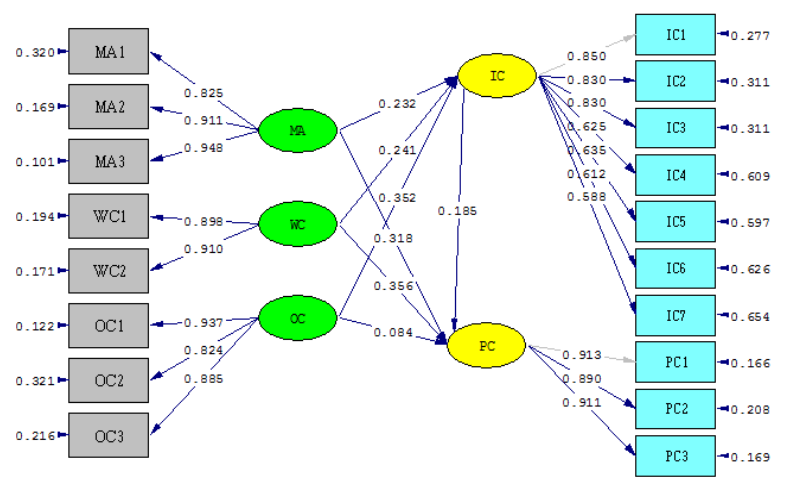

Figure 7. Overall Basic Model

Structural models are models that connect exogenous latent variables with endogenous latent variables or the relationship of endogenous variables with other endogenous variables. The calculation results describe the calculation model as follows.

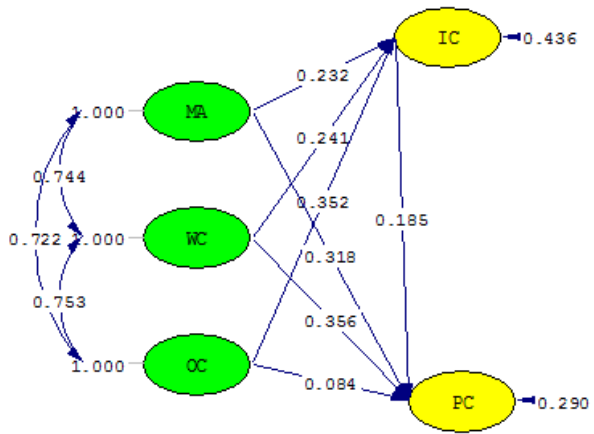

Figure 8. Structural Model

The t-value of this model can be illustrated as follow.

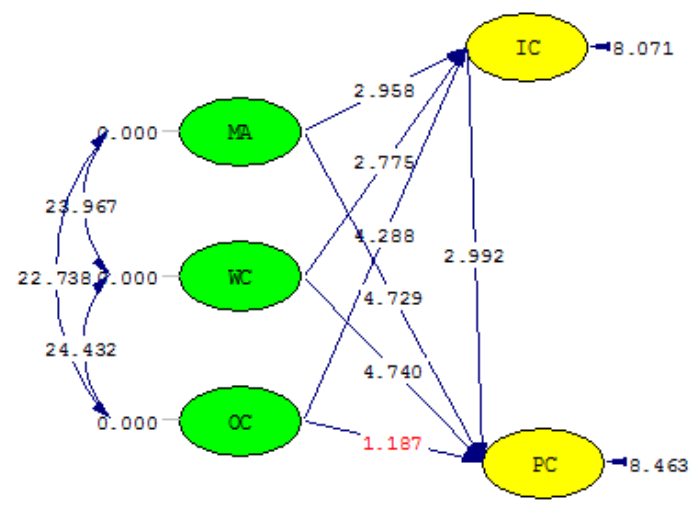

Figure 9. t-value

Overall, the path calculation and significance for each model can be summarized as follows.

Table 1. Summarized of Structural Model

\begin{tabular}{|c|c|c|c|c|c|}
\hline \multicolumn{2}{|r|}{ Model } & \multirow{2}{*}{$\begin{array}{l}\text { Path } \\
0,232 \\
\end{array}$} & \multirow{2}{*}{$\begin{array}{l}\text { t-stat } \\
2,958 \\
\end{array}$} & \multirow{2}{*}{$\begin{array}{l}\text { Significance } \\
\text { Significant }\end{array}$} & \multirow{3}{*}{$\begin{array}{c}\begin{array}{c}\mathbf{R}^{2} \text { and } \mathbf{e} \\
\text { F-hitung } \\
\text { (Significance) }\end{array} \\
\mathrm{RSq}=0,564 ; \\
\mathrm{e}=0,436 \\
12,81\end{array}$} \\
\hline \multirow[t]{3}{*}{ IC } & $\mathrm{MA} \rightarrow \mathrm{IC}$ & & & & \\
\hline & $\mathrm{WC} \rightarrow \mathrm{IC}$ & 0,241 & 2,775 & Significant & \\
\hline & $\mathrm{OC} \rightarrow \mathrm{IC}$ & 0.352 & 4.288 & Significant & \\
\hline \multirow[t]{4}{*}{ PC } & $\mathrm{MA} \rightarrow \mathrm{PC}$ & 0,318 & 4,729 & Significant & \multirow{4}{*}{$\begin{array}{c}\mathrm{RSq}=0,710 \\
\mathrm{e}=0,290 \\
3,56 \\
\text { (Significant) }\end{array}$} \\
\hline & $\mathrm{WC} \rightarrow \mathrm{PC}$ & 0,356 & 4,740 & Significant & \\
\hline & $\mathrm{OC} \rightarrow \mathrm{PC}$ & 0,084 & & Insignificant & \\
\hline & $\mathrm{IC} \rightarrow \mathrm{PC}$ & 0,185 & 2,992 & Significant & \\
\hline
\end{tabular}

Level of significance $a=0,05$.

By referring to the second model, the decomposition of direct, indirect, and total influence of the managerial ability, work culture, and organizational characteristics model on Innovation capability and its Implications on Performance of Crafters in Tapis Small and Medium Enterprises in Lampung Province, can be presented as follows: 
Table 2. Decomposition of Direct, Indirect and Total Effects

\begin{tabular}{|l|c|c|c|}
\hline \multirow{2}{*}{ Path } & \multicolumn{2}{|c|}{ Effects } & \multirow{2}{*}{ Total } \\
\cline { 2 - 3 } & Direct & Indirect & \\
\hline $\mathrm{MA} \rightarrow \mathrm{IC}$ & 0,232 & - & 0,232 \\
\hline $\mathrm{WC} \rightarrow \mathrm{IC}$ & 0,241 & - & 0,241 \\
\hline $\mathrm{OC} \rightarrow \mathrm{IC}$ & 0,352 & - & 0,352 \\
\hline $\mathrm{MA} \rightarrow \mathrm{IC} \rightarrow \mathrm{PC}$ & 0,318 & 0,059 & 0,377 \\
\hline $\mathrm{WC} \rightarrow \mathrm{IC} \rightarrow \mathrm{PC}$ & 0,356 & 0,066 & 0,422 \\
\hline $\mathrm{OC} \rightarrow \mathrm{IC} \rightarrow \mathrm{PC}$ & 0,084 & 0,016 & 0,100 \\
\hline $\mathrm{IC} \rightarrow \mathrm{PC}$ & 0,185 & - & 0,185 \\
\hline
\end{tabular}

Source: Data Processing (2017)

Table 2 shows that the total effect of managerial ability, work culture, and organizational characteristics will be greater if through innovation capability. The indirect effect of organizational culture on performance of crafters is relatively greater than the indirect effect of managerial ability and organizational characteristics, so that the total effect also tends to be greater, as well as the direct effect. Conditions indicate the importance of managerial ability and organizational culture for performance of crafters, through innovation capability at the Tapis Weaving SMEs in Lampung Province.

Innovation capability can strengthen managerial abilities, organizational culture, and organizational characteristics. The influence of organizational culture that is strengthened by innovation capability on performance of crafters, is the most powerful influence, followed by the influence of managerial ability, and finally organizational characteristics. This model basically shows that innovation capability can be an intervening variable for managerial ability, work culture, and organizational characteristics on performance of crafters. Significance test shows that almost all of the pathways significantly influence the performance of crafters, except for the organizational characteristics pathway which is proven to be insignificant. This condition shows that organizational characteristics cannot directly affect performance, but it first needs to go through innovation capability.

\section{Discussions}

Analysis of the influence of managerial ability, work culture, and organizational characteristics on innovation capability is related to the results of the first model testing (IC Model). MA, WC, and OC simultaneously influence the KI of Tapis SME crafters in Lampung Province. with a total effect of 0.564 or $56.4 \%$, which means that 0.436 or $43.6 \%$ is influenced by other factors not examined. Correlation between variables is a proportion of the total effect that is as a result of multiplying the value of the path coefficient with the correlation of each exogenous variable (MA, WC, and OC) with its endogenous variable (IC). On a scale of $100 \%$, it can be seen the percentage of contributions of each exogenous variable to endogenous variables, which shows that the percentage of OC's contribution to IC is relatively greater than the contribution of MA and WC to IC. These findings confirm the results of Helfat \& Peteraf
(2015) research which states the dynamic effect of managerial ability on innovation capability. Managers need to have dynamic managerial abilities so they can adapt to changes in the external environment through a series of strategic management through innovation and organizational learning.

This finding is also in line with the results of the study of Çakar \& Ertürk (2010). In this case, the dominant aspects in work culture are certainty at work, followed by mutual cooperation (collectivism), closeness to the leaders of SMEs, and finally is firmness towards results orientation. The influence of work culture on innovation capability can be intervened by the variable empowerment of employees so that the culture that is empowered will have an optimal impact on innovation capability in SMEs. Based on Slater et al. (2014) organizational characteristics have a significant impact on innovation capability. Conducive organizational characteristics can accelerate the process of innovation capability in relation to the product innovation process through discovery, incubation, and acceleration of the production process. In turn, innovation capability supported by appropriate organizational characteristics can have an impact on the measurement of individual performance and the performance of the organization itself.

Analysis of the influence of managerial ability, work culture, organizational characteristics, and innovation capability on the performance of crafters is related to the results of the second model testing (PC Model). In this case, MA, WC, OC, and IC simultaneously affect PCs in Tapis SMEs. with a total effect of 0.710 or $71.0 \%$, which means that 0.290 or $29.0 \%$ is influenced by other factors not examined. Correlation between variables is a proportion of the total effect that is as a result of multiplying the value of the path coefficient with the correlation of each exogenous variable (MA, WC, OC, and IC) with its endogenous variables (PC). On a scale of $100 \%$, it can be seen the percentage of the contribution of each exogenous variable to endogenous variables, which shows that the percentage of $\mathrm{MA}, \mathrm{KC}$, and IC contribution to $\mathrm{PC}$ is greater than $\mathrm{OC}$ to $\mathrm{PC}$. The research results of Camps et al. (2016) related to individual performance also confirmed the existence of significant influence of work culture capabilities and organizational learning capability on the performance of these individuals. Employees are directed to continue learning and learning related to the production and marketing processes, as well as technological innovations in producing quality products. One that stands out in this aspect of culture is a flexible culture, which emphasizes the flexibility for employees to continue learning so that the application of the employee's work culture can directly impact on individual performance.

This study found that organizational characteristics did not significantly influence the performance of crafters. The findings of this study are 
in line with the results of Ngacho \& Das (2014) related to the aspect of the size of the company that does not have a significant effect on performance. This can be confirmed from the findings in the field that SMEs with small size can actually have high performance of crafters, and vice versa. This is also related to the age of UKM, which is that SMEs that have long been established do not necessarily have a high level of performance of crafters, because it could be that newly established SMEs can also have a high level of performance of crafters as well. Other studies, such as Kanten et al., (2015) confirm that organizational structure can provide its own characteristics to the work of the craftsman and in turn on individual performance. The development of this capability is important because innovation plays an important role in the success and growth of SMEs. There are two important things that enables SMEs to implement innovation, namely resources (HR, finance, and technology) and strategy (vision, organizational strategy, innovation strategy, mission, and organizational goals).

\section{CONCLUSSION}

Managerial ability, work culture and organizational characteristic are proven to have a positive effect on Innovation capability both of partially and simultaneously. Managerial ability, work culture and organizational characteristic are proven to have a positive effect on Performance of crafters. In this case, an increase in performance of crafters can be determined by an increase in managerial ability. Innovation capability is proven to have a positive effect on performance of crafters. In this case, innovation capability can act as an intervening variable that reinforces the influence of managerial ability, organizational culture, and organizational characteristics on employee performance. Managerial ability, work culture, organizational characteristics, and innovation capability simultaneously have an influence on performance of crafters.

The suggestions that can be given are the three basic skills must be coupled with the competence of the crafters who are both the owner or manager. Therefore, one of the factors that needs to be improved is the role and participation of the craftsman as the owner or manager on a scheduled basis in training, seminars, workshops, exhibitions and bazaars. Improvements and normative work values need to be improved. Organizational characteristics in the resource element are relatively lower factors in determining the success of SMEs. Therefore, it still needs to be improved how to manage raw materials as effectively and efficiently as possible. Performance of crafters on the time element gives an understanding that, the time of completion of weaving becomes a determining factor both in terms of revenue and sales volume. Therefore, crafters need to be given methods of how to manage the available time

\section{REFERENCES}

Çakar, N. D., \& Ertürk, A. (2010). Comparing innovation capability of small and medium-sized enterprises: examining the effects of organizational culture and empowerment. Journal of Small Business Management, 48(3), 325-359.

Camps, J., Oltra, V., Aldás-Manzano, J., BuenaventuraVera, G., \& Torres-Carballo, F. (2016). Individual performance in turbulent environments: The role of organizational learning capability and employee flexibility. Human Resource Management, 55(3), 363383.

Chen, D. (2011). Research on performance management of Chinese SME. International Journal of Business and Management, 6(4), 263.

Fatoki, O. O. (2011). The impact of human, social and financial capital on the performance of small and medium-sized enterprises (SMEs) in South Africa. Journal of Social Sciences, 29(3), 193-204.

Hajar, I. (2015). The Effect of Business Strategy on Innovation and Firm Performance in the Small Industrial Sector. The International Journal of Engineering and Science, 4(2), 1-9.

Helfat, C. E., \& Peteraf, M. A. (2015). Managerial cognitive capabilities and the microfoundations of dynamic capabilities. Strategic Management Journal, 36(6), 831-850.

Ikupolati, A. O., Medubi, R. D., Obafunni, M. O., Adeyeye, M. M., \& Oni, E. O. (2017). Small and medium enterprises (SMEs) as a source of human capacity building in Nigeria. Journal of Small Business and Entrepreneurship, 5(1), 35-42.

Kanten, P., Kanten, S., \& Gurlek, M. (2015). The effects of organizational structures and learning organization on job embeddedness and individual adaptive performance. Procedia Economics and Finance, 23, 1358-1366.

Kurniawan, D., Lubis, A. R., \& Adam, M. (2012). Pengaruh budaya kerja dan motivasi kerja terhadap kinerja karyawan International Federation Red Cross (IFRC) Banda Aceh. Jurnal Ilmu Manajemen, 1(1), 132-146.

McPherson. (2007). Ownership structure of SME's and the challenges it presents to their Growth. Journal of Management, 34(3), 375-409.

Meliza. (2013). Faktor-faktor yang mempengaruhi persepsi kesuksesan usaha kecil menengah (UKM) di wilayah DKI Jakarta. Ekstensi Manajemen. Jakarta: PEFE Universitas Indonesia.

Mochklas, M. (2016). Role of Leader in Creating Organizational Culture and Product Innovation to Reach Sustainable Competitive Advantage (Study on Ngingas Metal Village SME of Sidoarjo, East Java). The International Journal of Business \& Management, 7(4), 251-256.

Ngacho, C., \& Das, D. (2014). A performance evaluation framework of development projects: An empirical study of Constituency Development Fund (CDF) construction projects in Kenya. International Journal of Project Management, 32(3), 492-507.

Rahab, Sulistyandari, \& Sudjono. (2011). The development of innovation capability of small medium enterprises through knowledge sharing process: an empirical study of Indonesian creative industry. International Journal of Business and Social Science, 2(21), 112-123. 
Rismawati. (2017). Budaya kerja, Motivasi dan peningkatan Quality of Worklife (QWL) dalam mempengaruhi kinerja perajin pada Industri Kecil Klaster Lurik di Kabupaten Klaten. ISEI Cabang Serang: Forum Ekonomi dan Sosial ke 1.

Sitohang, S. (2010). Pengaruh Kualitas Sumber Daya Manusia Terhadap Kinerja Pengrajin Sentra Industri Kecil Tenun Ikat. EKUITAS (Jurnal Ekonomi Dan Keuangan), 14(1), 57-81.

Siyamtinah, Sulistiyo, H., \& Rahmani, E. (2011). Model Peningkatan Kinerja melalui Kapabilitas Inovasi pada UKM di Semarang. Seminar Nasional Ilmu Ekonomi Terapan. Fakultas Ekonomi UNIMAS.

Slater, S. F., Mohr, J. J., \& Sengupta, S. (2014). Radical product innovation capability: Literature review, synthesis, and illustrative research propositions. Journal of Product Innovation Management, 31(3), 552-566.

Sulistiyani. (2010). Pengaruh Kemampuan Manajerial Kreativitas Program Pemasaran dan Kemampuan Berinovasi Terhadap Kinerja UKM di Kota Semarang. Jurnal Pemikiran \& Penelitian Ekonomi Islam, 1(1).

Yanuarto, E., \& Kumorohadi, U. (2013). Peran Kapabilitas Inovasi Terhadap Perbaikan Produk Usaha Kecil Menengah (UKM) Dengan Tekanan Lingkungan dan Ukuran Perusahaan Sebagai Variabel Moderasi (Studi pada UKM di Kabupaten Purbalingga). Performance, $16(2)$ 